\title{
Local institutions, actors, and natural resource governance in Kgalagadi Transfrontier
}

\section{Park and surrounds, South Africa.}

Gladman Thondhlana $^{1}$, Sheona Shackleton ${ }^{1}$ and James Blignaut ${ }^{2}$

${ }^{1}$ Rhodes University, Department of Environmental Science, P. O. Box 94, Grahamstown 6140, Republic of South Africa. Tel: +27 46603 7007. Mailfax: +27 865493095

${ }^{2}$ University of Pretoria, Department of Economics, Private Bag X20 Hatfield 0028, Republic of South Africa Corresponding author. Email: G.Thondhlana@ru.ac.za

\begin{abstract}
Crafting local institutions to allow more effective decision-making in the management of and access to natural resources in and beyond parks has long been considered key to collaborative governance. South Africa, in particular, has vigorously pursued collaborative governance as a desired approach to managing natural resources as evident in the new arrangements for previously restricted parks. However, though the discourse of collaborative governance has occupied conservation thinking and practice globally, few studies have looked at the interplay between local institutions, actors and collaborative governance involving indigenous huntergatherer communities in Southern Africa. In response, we assess the local actors and institutions that were put in place to facilitate collaborative governance of natural resources in the Kgalagadi Transfrontier Park and its surrounds in South Africa. Our findings show that though collaborative governance has a practical appeal, it is hampered by lack of participation in decision-making, information dissemination, transparency, trust and accountability, power relations, divergent interests and unequal access to natural resources. The findings also draw our attention to issues of heterogeneity, even within indigenous communities assumed to be homogenous by local conservation authorities as reflected in land settlement agreements in co-managed parks. We argue that collaborative governance arrangements need to reflect and be understood within the broader background of complex local realities.
\end{abstract}

Keywords: Institutions; actors; parks; natural resources; collaborative governance; livelihoods 


\section{Introduction}

A myriad of parks and their surrounds continue to be the traditional homelands of indigenous and local communities worldwide (Brockington et al., 2006; Holden, 2007; Finer et al., 2009; Ellis, 2010; Coe, 2013). These areas are endowed with a variety of natural resources that are crucial for local residents' livelihoods (Brockington et al., 2006; Adams and Hutton, 2007; Thondhlana et al., 2012). With the realisation that a 'no access' policy to protected area management can result in serious social costs that undermine both local livelihoods and conservation goals, approaches to managing natural resources have shifted from 'protectionist' to 'collaborative' models (Adams and Hutton, 2007; Springer, 2009). These new collaborative approaches emphasise the importance of including multiple actors and crafting local institutions that include users in decision-making regarding access and management of natural resources (Lockwood et al., 2010). Effective local institutions for collective action are critical for collaborative governance of natural resources (Ostrom, 1990; Kepe, 2008a; Lockwood et al., 2010).

In many conservation projects in sub-Saharan Africa multi-actor institutions have been established to facilitate collaborative natural resource governance both in parks and beyond them (Jones, 2007; Petursson et al., 2011; 2013). Collaborative arrangements are predominantly informed by participatory discourses (Cundill et al. 2013). Participatory discourses often argue that preconditions such as ensuring transparency, legitimacy, social justice, building trust and distributing costs and risks more equitably among actors can contribute to collaborative governance (e.g. Ostrom, 1990; Collomb et al., 2010; Coe, 2013; Mwakaje et al., 2013). 
Lockwood et al. (2010) reflect on these conditions in their list of the key ingredients for successful collaborative governance. These include (a) inclusiveness - whether the opportunity to participate in and influence decision-making process is available to every interested actor; (b) fairness - respect and attention is given to all actors' views and a biasfree decision-making process exists; (c) participation and legitimacy - where governance is characterised by authentic participation and considers the views of all concerned actors; (d) transparency - where the decision-making process is visible and information about governance and performance of programmes is provided to all actors, and (e) accountability where decision makers are responsible to all actors and demonstrate how responsibilities are fulfilled.

Based on uncritical use of these, collaborative governance is often packaged by conservation agencies as a desirable natural resources management approach strategy for local economic development and poverty alleviation (Brockington et al., 2006; Adams and Hutton, 2007; Kepe et al. 2005; 2008). However, collaborative governance in practice has been shown to be extremely complex and many attempts have demonstrated limited success (Campbell et al., 2001a; Coe, 2013; Mwakaje et al., 2013). The promise of benefit-sharing under collaborative arrangements have not been fulfilled and in most cases conflicts tend to be the rule rather than the exception (Brockington et al., 2006; Cundill et al., 2003; Redpath et al., 2013). Particularly, it is argued that collaborative governance tends to skim over institutional complexities, especially those caused by the dominant role of the state in initiating collaborative processes (Davies and White, 2012; Cundill et al., 2013) and the inclusion of a multitude of actors who often have varying interests (Campbell et al., 2001b; Thondhlana et al., 2011). 
Despite these critiques, South Africa has, since its transition to democratic rule in 1994, pursued to emulate this participatory natural resource governance model, by implementing collaborative governance in parks and beyond them (Kepe et al., 2005; Kepe, 2008b; Holmes-Watts and Watts, 2008; Cundill et al., 2013). The embracing of collaborative governance in South African parks is nowhere more evident than in the Kgalagadi Transfrontier Park (KTP) where the indigenous San community has ownership and use rights.

The KTP case is of wider scholarly significance in relation to several collaborative governance arrangements. First, it is the first transfrontier/peace park in Africa (Hanks, 2003) and the site of a landmark land restitution claim that awarded the indigenous ${ }^{1}$ \#Khomani San $^{2}$ community collective ownership of land both inside and outside the park (Thondhlana et al., 2011). Almost 15 years have passed since the land claim was settled. The KTP thus presents a long-established example of a collaborative governance system where trends, experiences and key lessons can be identified and reflected in the literature. This involvement of the San community in the collaborative governance of resources in the park has resulted in the KTP being viewed as a flagship conservation model in South Africa and beyond (Hanks, 2003). According to Ramutsindela (2007), the KTP has, since its establishment, provided the proponents of Transfrontier Conservation Areas (TFCAs) with arguments to leverage some responsiveness in establishing TFCAs in the region. A second point of significance is that, the San people are commonly believed to be culturally homogeneous by local conservation

\footnotetext{
${ }^{1}$ We define indigenous communities as communities, peoples and nations which have a historical continuity with pre-invasion and pre-colonial societies that developed on their territories and consider themselves distinct from other sectors of the societies now prevailing on those territories, or parts of them (United Nations, 1994).

${ }^{2}$ The term \#Khomani San refers to a collective of various San ethnic groups who came together to claim their ancestral land at Kgalagadi Transfrontier Park. The original land claimant (the Kruiper family) was considered not big enough to claim a large piece of land so other San family groups were allowed to join in (Holden, 2007).
} 
authorities (see Bosch and Hirschfeld, 2002; SANParks, 2006; Holden, 2007), but evidence suggest this may be far from the case (Robins, 2001; Thondhlana and Shackleton, 2013). Assumptions of homogeneity often form the basis for many collaborative agreements in other co-managed South African parks (Cundill et al. 2013), with serious repercussions. Further, conflicts in co-managed parks, such as the KTP, have been reported post land resettlement (Robins, 2001; Kepe, 2008a). However, there are surprisingly few in-depth analyses of the interplay between institutions, actors and collaborative governance in co-managed parks in South Africa. An analysis of this interplay is central for natural resources management, in terms of informing various institutional interventions for effective collaborative governance. Such an analysis is imperative not least because a third of all protected areas in South Africa are under land claims and collaborative governance is the expected outcome of land settlement agreements (Cundill et al., 2013) and more broadly parks present a platform where different actors with different interests converge (Ramutsindela, 2007).

The objective of this paper is thus to explore the links between local institutions, actors and collaborative governance of natural resources inside and outside the KTP. We focus on how the emerging institutional arrangements impact outcomes and highlight the conditions under which collaborative governance is most likely to be achieved and sustained. In the next section, we briefly define governance and institutions as framed and used in this paper, as well as background on the KTP land claim. This is followed by a description of the data collection methods. In our presentation and analysis of the results in section 4, we first provide a descriptive account of the actors and institutions inside and outside the KTP because of a complex set-up - where the park ideally has to be managed in unison with the surrounding communal lands and we then follow this by an analysis of the institutional 
interplays and outcomes. In the last section we provide the conclusions and recommendations.

\section{Defining governance and institutions}

We define governance following Graham et al. (2003: ii) as "the interactions among structures, processes and traditions that determine how power and responsibilities are exercised, how decisions are taken, and how citizens or other stakeholders have their say". Governance processes and structures such as contracts, networks, policies, cultural practices, legislation and rules are institutional mechanisms used to make collaborative governance work. Following North (1990), we consider institutions as the 'rules of the game' for instance regulations, agreements, constitutions, values and social practices that structure interactions. These institutions mediate access to and control over natural resources by determining whether or not one is eligible for making decisions, the actions permitted or forbidden, procedures for actions and type of information one can get in a specific context (Ostrom, 1990). They reflect the vested values and interests of various actors - realised through contested and negotiated arrangements (Young, 2002; Kepe, 2008a), which has implications for collaborative governance of natural resources. We view actors as players whose activities guide or are guided by the institutions and governance arrangements in which they participate (Young, 2002).

\section{Study area and data collection}

\subsection{Kgalagadi Transfrontier Park (KTP) and its surrounds}

The KTP is situated in southern Kalahari, in the Northern Cape Province of South Africa and southern part of Botswana from $22^{\circ} 10^{\prime \prime}$ East, $20^{\circ} 0^{\prime \prime}$ West, $24^{\circ} 6$ " North and $26^{\circ} 28^{\prime \prime}$ South (Figure 1). Formed after the amalgamation of the former Kalahari Gemsbok National Park in 
South Africa and the Gemsbok National Park in Botswana in April 2000, the KTP consists of an area of approximately $38000 \mathrm{~km}^{2}$, with $25 \%$ of the park lying on the South African side. The establishment of the Kalahari Gemsbok National Park in 1931, under the previous 'fences and fines' regime, resulted in the displacement of the indigenous people of the Kalahari, the San (Bradstock, 2006; Holden, 2007). This land dispossession led to infringement of San rights to resource use, obvious livelihood hardships and park-people conflicts (Thondhlana et al., 2011). However, following the 1999 land claim in the KTP, the San were awarded about 25000 ha of land (jointly owned as a Contract Park with the nearby

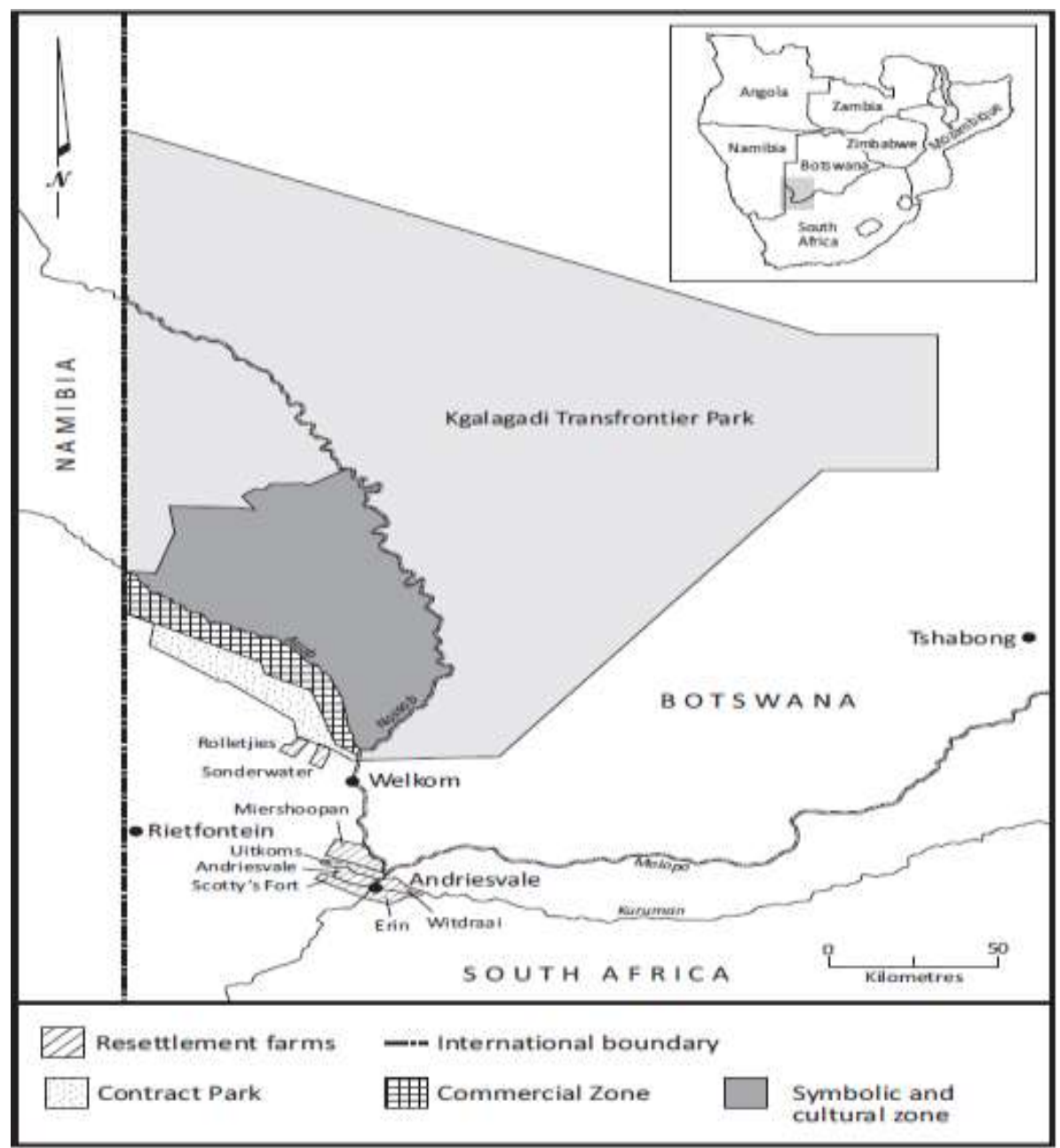

Figure 1. Location of Kgalagadi Transfrontier Park and the surrounding resettlement farms 
Mier $^{3}$ community), some access rights in different KTP zones and 42000 ha of resettlement farms outside the KTP (Figure 1). This case study is confined to the South African portion of the KTP.

Following the KTP land claim several actors came together to craft the necessary local organisations and institutions to facilitate the collaborative governance of resources in the different zones and land parcels. There are different rights and institutions for these different KTP zones as described later. This land claim was consistent with the South African Government land restitution programme aimed at restoring land to people who were displaced forcibly from their ancestral land due to the previous discriminatory legislation (Bradstock, 2006). Most San members who were part of the restitution claim, are distinct groups of San families who were scattered all over South Africa but came together to form a large group to lodge a land claim as required by law (Holden, 2007). The original land claimants - the Kruiper family was small - but by 1999 when the land settlement agreement was signed, almost 300 people were registered as San claimants (SAHRC, 2004). It is reported that the total number of claimants has surpassed 1000 since the land claim (Bradstock, 2006). The San members live in the resettlement farms located about $60 \mathrm{~km}$ away from the KTP, while a few live in small settlements such as Welkom and Rietfontein (Figure 1). They combine different sources of income for their livelihoods, typically including natural resource use, working for low wages on neighbouring farms, social welfare grants, craftmaking and picture and filming appearances (Thondhlana et al., 2012).

\footnotetext{
${ }^{3}$ The Mier, an ethnically mixed 'coloured' community, claimed land at the same time with the San arguing they were forcefully displaced from their ancestral land, and were awarded about 25000 ha of park land that is jointly owned with the San as a Contract Park.
} 
The Kalahari region has a harsh climate. It receives annual rainfall of less than $200 \mathrm{~mm}$ and temperature can reach up to $45^{\circ} \mathrm{C}$ in summer and less than zero in winter (van Rooyen, 1998). In spite of its physically dry and harsh environment, the Kalahari region has a rich biodiversity including arid system adapted plants. The vegetation of the region is described by Mucina and Rutherford (2006) as a mosaic of karroid bushveld, thornveld and shrubby grasslands characterised by the presence of small trees, tall shrubs, low shrubs, herbs, succulent herbs and grasses.

\subsection{Data collection}

We drew on both primary (household surveys, key informant interviews and observations) and secondary data sources including books, journals articles, minutes, management plans and the Land Settlement Agreement). In phase one of field work, we targeted all San households for a broader-based survey, which looked at valuation of natural resource use and the institutional and governance arrangements inside and outside the KTP. In total we administered 100 structured questionnaires. The section on institutions (in this broad-based survey questionnaire) captured information on the actors and organisations, the formal and informal institutions inside and outside the KTP, local people's membership in organisations, participation in decision-making and perspectives on the patterns of interactions among the different actors.

In the second phase, our survey only focussed on governance issues. We randomly administered 50 structured questionnaires to the set of 100 households interviewed in the broad-based survey (phase one). Questions were specifically tailored to capture people's perceptions and knowledge of the actors and institutions inside and outside the KTP and indicators of governance such as perceptions on relations, participation in decision-making, 
benefits from natural resources and tourism inside and outside the KTP, information dissemination, accountability and transparency and attitudes towards leaders and collective activities, following Collomb et al. (2010). We also conducted in-depth personal interviews on governance issues with a subset of respondents from the second survey (with a fair representation of traditionalists, modernists, men, women and youth). These interviews provided more insight into the nature, functions and impacts of the various actors, organisations and institutions and what this means for collective governance of natural resource management in the KTP and resettlement farms.

Through semi-structured personal interviews with key actors such as members of the KTP management, Joint Management Board, Department of Land Affairs and local NGOs we were able to capture information on these different actors' interests, whom and what they represent (value systems), what they say they do and what they actually do in practice, forms of interactions among them and outcomes (e.g. livelihood issues, points of cohesion and conflicts). The KTP Land Settlement Agreement, also known as the !Ae!Hai Kalahari Heritage Park Agreement (Borsch and Hirschfeld, 2002) and the Protocols for Sustainable Resource Use and Cultural Activities document were important sources of information on aspects related to rules for natural resource access and use, and decision-making powers and the rights, relationships, responsibilities and returns of the different actors. The multiple sources of data allowed for triangulation to validate the gathered information while interviewing of different actors allowed us to get multiple perspectives on certain issues. Literature was used to reflect on the general discourses on access to and use of natural resources inside and outside parks. 


\section{GOVERNMENT}

South African National

Parks (SANParks)

- Natural resource

conservation

- KTP maintenance

Joint Management

Board (JMB)

- Conservation, traditional use of resources, livelihoods

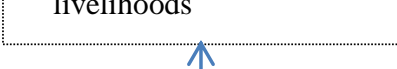

\section{木}

San Park Committee

- Sits in the JMB

- Represents the interests of all and report to the San CPA members

South African San Institute

- San cultural heritage and linguistic issues

- Financial management of San community game farms and bush camps

- Traditional guiding and tracking

- Providing information on income and expenditure to San CPA members
Department of Land Affairs

- Ecotourism initiatives inside and outside the KTP

- Registration of CPAs and

\section{administration of San CPA and outside the KTP and outside the KTP}

\section{Department of}

Environmental Affairs and

Tourism

- Funding for ecotourism inside

\section{COMMUNITY}

San traditional subcommittee

- Traditional plant

monitoring and evaluation

- Preservation of resources and culture

San Communal

Property Association

Management

Committee

- Report to CPA members

Figure 2: A plethora of actors and their primary focus

\subsection{Actors inside and outside the Kgalagadi Transfrontier Park (KTP)}

Several actors are involved in collaborative governance arrangements in the various KTP zones and the adjacent resettlement farms (Figure 2). These actors are a combination of government, non-government and community actors, who address conservation from different value systems and discourses (Figure 2). Interaction between these actors is achieved through co-management organisations and other sub-committees formed after the land claim namely the Joint Management Board, the San Park Committee, the San 
Traditional Sub-committee (Bushmen Committee) and the Communal Property Association (CPA) Management Committee. These committees were formed as a result of the stipulations in the Land Settlement Agreement (hereinafter the agreement) between SANParks and the local communities.

Land inside the KTP is managed by the Joint Management Board, a committee where representatives of SANParks and San community take decisions on the management of the Contract Park. The San community is represented by a Park Committee (a group of elected San members), with the advice of Traditional Sub-committee and Technical Advisors. In principle, the Park Committee represents the common interests of the San constituency. The Traditional Sub-committee consists of a group of knowledgeable San elders who give wisdom and advice on sustainable natural resource practices through indigenous knowledge systems (e.g. social norms) both in the KTP and the resettlement farms.

The key actor responsible for management of the communal resettlement land outside the KTP is the CPA Management Committee. The Communal Property Act requires Communal Property Associations to elect a CPA Management Committee for the management of land held in common by a group of rights holders (SAHRC, 2004). However, there was no functional CPA Management Committee at the time of the study due to reasons related to internal conflicts, maladministration, mismanagement of funds and corruption (see Ellis, 2010; Thondhlana et al., 2011). Key informant interviews revealed that the term of the first CPA Management Committee ended in April 2001 after an audit initiated by the DLA found the committee 'guilty of gross mismanagement of funds' (SAHRC, 2004). 
A new CPA Management Committee was later elected in July 2001, but it is reported that this committee's term of office also ended controversially during 2002 with the DLA having to step in to prevent the sale of Erin farm to cover debts incurred by CPA Management Committee members. In the same year, the DLA lodged a successful application to the High Court to place the San CPA under its administration in terms of the CPA Act. It is reported that a new CPA Management Committee was elected in 2003 (and other committees later) but these committees were under the administration of the DLA and therefore did not have the decision-making powers (e.g. selling or leasing community assets such as land) of such a body in terms of the CPA Act. The duration of external administration is still unclear due to the absence of an explicitly set time-frame and conditions under which administration will become internal. This has effectively left an institutional vacuum. In the absence of a functional CPA Committee, various actors such as San Technical Advisors and the South African San Institute tended to work with selected individuals or groups of individuals within the San community. The respondents reported knowledge of different committees, some of which had long been disbanded, which is symptomatic of a dysfunctional governance system. The situation also points to the fact that collaborative governance is a platform where many actors with different objectives and interests emerge. This means that when thinking about collaborative governance of natural resources, the possibility of multiple actors and how their different interests could be addressed within a broader shared vision should be considered.

\subsection{Institutions inside the KTP}

Both formal and informal institutions in the form of traditional norms, regulations and agreements contribute to the governance of natural resources in the KTP under the land settlement agreement. Formal institutions include the agreement, the Protocols for Sustainable Resource Use (here in after the protocols) and those outlined in the Protected 
Areas Act. The agreement is a formal pact for establishing a positive and co-operative relationship between the community parties and SANParks. It is reported that representatives of the different parties; the Commission on Restitution of Land Rights, San CPA Management Committee, lawyers for the San community and SANParks and other government departments were involved in the land claim negotiations and the subsequent development of the agreement (Bosch and Hirschfeld, 2002). The agreement spells out the roles of the various actors and their sub-committees and access to and benefits from natural resources. In line with the agreement, the KTP land parcel is divided into several zones: the Contract Park, Commercial Zone, Symbolic and Cultural Zone and rest of park (Figure 1).

In the Contract Park, the San have access rights for sustainable economic, symbolic and cultural uses that are compatible with conservation including collection of medicinal plants and traditional hunting. Livestock grazing, mining and permanent housing are prohibited. The Commercial Zone belongs to SANParks, but the San have access for commercial joint venture use (e.g. ecotourism) with SANParks. The Symbolic and Cultural Zone belongs to SANParks, but with San access for uses such as visiting culturally and symbolically important sites, traditional gathering of food and medicines and educational trips. The last zone belongs to SANParks with no local community access. The obligation to maintain infrastructure related to conservation and ecological integrity in all the land zones in the KTP lies with SANParks (Bosch and Hirschfeld, 2002).

The protocols specify what kind of natural resources are to be harvested, where, by who and when. The development of the protocols was a result of an initiation from San elders (also known as traditionalists), the Park Committee and interested San community members. These provisions have not been fully implemented, are not legally binding and are subservient to the 
Protected Areas Act. The Act is the primary legal institution that provides for the protection of biodiversity in South African parks. According to the agreement, collaborative governance arrangements in the different land zones (Figure 1) in the KTP should be within the provisions of the Protected Areas Act. Provisions on Section 2 (e) and (f) of the Act respectively promote sustainable utilisation of protected areas for the benefit of people, in a manner that would preserve the ecological character of such areas and participation of local communities, where appropriate.

However, in all its dealings with local communities in the KTP, SANParks has been unequivocal in its primary objective. For example, in the protocols, SANParks states that resource use within the KTP will ultimately not be towards the support of community livelihoods but rather serve as a way by which the San can re-connect with their cultural heritage. It is reported that natural resource use as a livelihood strategy will take place on the resettlement farms outside the KTP. There have been proposals in the protocols to grow important plant species on the resettlement farms awarded to the San to minimise access to the KTP. Furthermore, there is suspicion and discourse about local people's ability to use resources sustainably as explicitly illustrated by SANParks' statement in the protocols that "an underlying threat to sustainable resource use is that local people may over-utilise resources for fear of not being allowed to harvest them again”.

Despite provisions for sustainable utilisation of natural resources by local communities in the agreement, hunting in the KTP is not yet allowed and requires cultural practices and traditional dance. Rules for hunting as per the agreement require traditional hunting methods (bow and arrow) and materials be used, including assegais and knobkerries, but long bows are prohibited. Taking hunted meat out of the KTP is also forbidden. Resource access rules in 
the agreement state that traditional rituals are supposed to be respected and applied, and San youths will be included according to custom. However when hunting, the San people are not permitted to roam along tourist routes in the KTP since this would 'spoil the tourist experience'. Paradoxically, it is the widely marketed San legacy and traditional way of life that is partly employed to attract tourists to the KTP. Respondents viewed these rules as unfair and felt that the playing field was not level. They perceived the institutions for resource use in the KTP (as defined by the agreement) to be very restrictive and believed that SANParks wielded all the power and control in decision-making regarding natural resource management in the park.

According to Cundill et al. (2013 p. 172), "this trend in South Africa can be traced to a Memorandum of Agreement that was signed in 2007 between national ministers, which stated that protected areas under land claim will remain under conservation in perpetuity as a non-negotiable element of the settlement of claims". Our findings are generally consistent with experiences elsewhere where conservation agencies are often found to have conservation objectives uppermost in their mandates and principles, with their expertise and experience focused on conservation (e.g. Kepe et al. 2005; Holmes-Watts and Watts, 2008).

\subsection{Institutions in the San resettlement farms}

The restitution of communal land rights procedure in South Africa involves an observance of the Communal Property Associations Act 28 of 1996. The Act enables communities to form juristic bodies, known as Communal Property Associations (CPAs), in order to acquire, hold and manage property on a basis agreed to by members of a community in terms of a written CPA constitution. The CPA constitution is the primary institution for management of land awarded to local communities under the land restitution programme. According to the San 
CPA constitution, the resettlement farms are divided for various activities as follows: game farming (Miershoop Pan), traditional purposes and ecotourism (Witdraai, Erin, Sonderwater and Rolletjies), subsistence use (Uitkoms) and livestock farming (Scotty's Ford and Andriesvale) (Figure 1).

However, while the constitution is reasonably clear on the substantive access and use rights that households may have in the different farms, the practice has been that local people disregard these stipulations, amid heightened internal conflicts. For example, the rules stipulate that specific livelihood activities (such as livestock grazing and subsistence harvesting of resources) should be practiced as per the farm zonation and the resettlement farms shall benefit only registered San CPA members. However, there were reports that some San members sell out their grazing rights to the nearby Mier community for personal gains.

With regards to the state of the CPA constitution, $96 \%$ of respondents perceived that the constitution was either 'bad or very bad' arguing that the constitution did not manage natural resources well. Most San respondents said they did not participate in the designing of the rules for natural resource access in the resettlement farms and hence did not have a clear idea of the direction of conservation in the area. Many respondents exhibited little knowledge of the CPA constitution for natural resource management in the resettlement farms - perhaps illustrative of lack of involvement in decision-making processes. The overall feeling among more than half of respondents $(56 \%)$ was that the constitution, did not bring their desired livelihood outcomes and that this was leading to non-conformance to rules, over-use and poaching of resources. Some respondents also felt that the game hunting fee charged for hunting in the communal game farms was not equally enforced across all community members, as some members connected to community leaders hunted without hunting 
licenses. When asked if they followed the constitution, respondents said they 'seldom followed it'. Traditional informal institutions for resource management such as cultural practices are also generally regarded as important among the San but most respondents, especially the youths interviewed reported that they knew little about these (see also Thondhlana and Shackleton, 2015).

\subsection{Decision-making and power relations inside and outside the KTP}

Inclusiveness of every stakeholder and fairness in decision-making is critical for collaborative governance. Our findings show that a majority of respondents (80\%) felt SANParks rules, ironically approved by the San Traditional Sub-committee, do not represent the interests of all San members. Concerns were raised that the Traditional Sub-committee arbitrarily decided on issues of land administration especially in the Contract Park, arguing for example, that the development process of the protocols was not inclusive and only reflected the interests of 'traditionalists'. Despite the growing discontent expressed by some of the respondents, local relations between SANParks and the San seemed affable with most respondents $(80 \%)$ in the second survey reporting a good relationship with the KTP, albeit not the 'desired' one. Further, narratives amongst interviewed KTP management seemed to support the good relationship with local people saying that the Contract Park was properly managed and meeting its conservation objectives under the current land settlement agreement. As one KTP management staff echoed, "Kgalagadi Transfrontier Park is in the spotlight, with this conservation with people, SANParks get mileage and overseas markets are attracted".

The agreement stipulates the San people can make suggestions about resource use rules in the KTP, but SANParks yields the most power to influence resource use decisions as they have 
the overall mandate to maintain ecological integrity in the KTP (Bosch and Hirschfeld, 2002). In short, institutions for resource access and use in the KTP were perceived by respondents to be restrictive - raising challenging questions of whether or not park regimes are willing to incorporate local community livelihood needs (see Holmes-Watts and Watts, 2008). Our findings generally suggest that despite being land owners, and partners in the land settlement agreement, some San community members do not appear to have any real influence and say in decision-making regarding the management of natural resources in the KTP. These findings corroborate the work of Cundill et al. (2013) on four protected areas in South Africa and Moswete et al. (2012) on the KTP in Botswana which support the contention that park institutions have historically held the view that human beings and natural resources should be separated (Adams and Hutton, 2007; Brockington et al. 2006).

\subsection{Community heterogeneity}

Part of the challenges of the institutions and collaborative governance both inside and outside the KTP is dealing with a heterogeneous community. Despite representations of a 'homogenous' San community in conservation efforts at KTP and surrounds, there are serious divisions especially between the 'original claimants' and their traditional leadership, and those that joined the land claim later and who have a more 'modern' outlook. The original land claimants were the Kruiper family members, but other San members were required to join the initial land claimants to make up a bigger community, as required by law, to claim a large piece of land (SAHRC, 2004; Holden, 2007; Ellis, 2010). On the one hand, the so called 'traditionalists' strongly identify with the traditional San culture, identity and subsistence use of resources (Thondhlana et al., 2011). Their predominant aim is to establish institutions that restore and protect the San traditional values. On the other hand, the 'modernists' view their land as a pathway out of poverty and therefore believe that 
institutions should allow land inside and outside the KTP to be used productively and sustainably (Thondhlana et al., 2011). This shows that the notion of 'community' in settlement agreements is problematic as it is fraught with misunderstandings and uninformed assumptions.

Therefore framing of institutions and development projects in one 'mould' is likely to have divisive effects among communities which could compromise collective action. For example, SANParks largely uses the traditionalist narrative in framing rules for resource use in the KTP. However, framing the San culture as pristine, cohesive and undiluted was viewed by some San respondents as a strategy by SANParks to gain the power to constrain resource use and marginalise some 'modernised' community members. Another case in point is the funding provided by the National Lotteries Board through the Peace Parks Foundation to support the San to pursue livelihood opportunities and cultural regeneration through traditional use of natural resources in the Contract Park which is a source of contention within the community. Some 'modernist' respondents felt that this money did not benefit the whole community but only individuals who were perceived to be strong 'traditionalists'.

Our analysis generally shows that the traditionalist narrative is typically used by different actors to strategically position themselves to gain access into the different benefit streams in the KTP and resettlement farms, leading to heightened conflicts within the San community. Robins (2001) contends that the traditionalist-modernist conflict is a product of and perpetuated by NGO objectives and institutions that classify communities based on cultural background. This lack of meaningful inclusion and unfairness in decision-making often does not rest well with some members of the society - which perhaps explains the reported resentment towards collaborative governance, as suggested by Lockwood et al. (2010). 
Table 1: Main actors and their primary focus

\begin{tabular}{|c|c|}
\hline Main actors & Values and main focus \\
\hline $\begin{array}{l}\text { Government actors } \\
\text { South African National Parks (SANParks), } \\
\text { KTP management }\end{array}$ & $\begin{array}{l}\text { - } \quad \text { Natural resource conservation } \\
\text { - } \quad \text { KTP maintenance }\end{array}$ \\
\hline Department of Land Affairs & $\begin{array}{l}\text { - } \text { Eco-tourism initiatives inside and outside the KTP } \\
\text { - } \text { Registration of CPAs and administration of San CPA } \\
\text { committee }\end{array}$ \\
\hline $\begin{array}{l}\text { Department of Environmental Affairs and } \\
\text { Tourism }\end{array}$ & - $\quad$ Funding for eco-tourism inside and outside the KTP \\
\hline $\begin{array}{l}\text { Community actors } \\
\text { San community members }\end{array}$ & $\begin{array}{l}\text { - Mixed but largely divided between 'traditionalists' for } \\
\text { traditional use versus 'modernists' for resource } \\
\text { commercialisation }\end{array}$ \\
\hline CPA Management Committee & - $\quad$ Report to CPA members \\
\hline San Traditional Sub-committee & 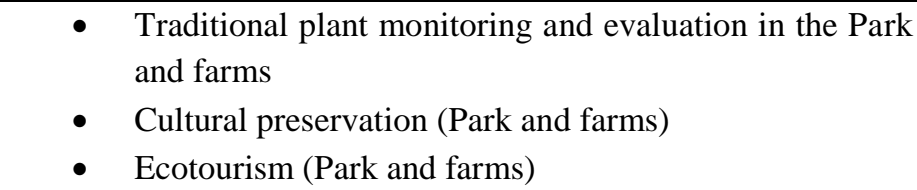 \\
\hline $\begin{array}{l}\text { Joint Management Board } \\
\text { (government-community actor) } \\
\text { San Park committee (Sub-committee) }\end{array}$ & $\begin{array}{l}\text { - } \text { Conservation, traditional use of resources, livelihoods } \\
\text { - KTP access } \\
\text { - } \text { Report to San CPA members through the San } \\
\text { representatives in the JMB, known as the Park } \\
\text { committee }\end{array}$ \\
\hline San Technical Advisors & $\begin{array}{l}\text { - Conservation and livelihoods inside and outside the } \\
\text { KTP } \\
\text { - } \quad \text { Monitoring and evaluation of natural resources in KTP }\end{array}$ \\
\hline $\begin{array}{l}\text { NGOS } \\
\text { South African San Institute } \\
\text { Finance committee (Sub-committee) }\end{array}$ & $\begin{array}{l}\text { - San cultural heritage and linguistic issues } \\
\text { - Financial management of San community game farms } \\
\text { (Miershoop and Witdraai) and Bush Camps } \\
\text { - Traditional guiding and tracking } \\
\text { Provide information on income and expenditure to San } \\
\text { CPA members through the Finance Committee }\end{array}$ \\
\hline Peace Parks Foundation & $\begin{array}{l}\text { - Conservation of biodiversity in transfrontier/peace } \\
\text { parks } \\
\text { - } \quad \text { Cultural preservation and eco-tourism (in the KTP) }\end{array}$ \\
\hline
\end{tabular}

\subsection{Benefit-sharing inside and outside the KTP}

All the households interviewed in phase one reported using natural resources though the level of dependence on different natural resources varied across households (see Thondhlana et al., 
2012). All the surveyed respondents collected different natural resources from the resettlement farms (Table 1). However, only 5\% of the respondents reported collecting medicinal plants from the KTP, corresponding to a few herbalists who had limited access for medicinal plant harvesting only in the Contract Park. Though poles and thatch grass for building purposes were collected by the highest number of households (97\%) from the resettlement farms, fuelwood was the most important resource in terms of the frequency of harvesting and the value to households. Less than $5 \%$ of the households reported getting benefits from eco-tourism enterprises (e.g. cash income and employment) from the farms. Many respondents claimed that the Erin and Miershoop Pan game farms and the bush camp in Witdraai farm were mismanaged by corrupt community leaders and the income generated from game farms was reportedly low, such that the actual impact of community game farms on their livelihoods was minimal.

In the KTP, the community lodge (!Xaus Lodge) in the Contract Park has been operational for several years but without any direct benefits to the San community. The lodge is currently operated by a private concessionaire and profits are shared equally between the three Joint Management Board parties and the concessionaire, under a policy of revenue sharing according to the agreement. However, the interviewed respondents reported no cash income apart from a few seasonal jobs and opportunities for selling crafts at the community lodge. Only $6 \%$ of the respondents reported benefitting from employment from the KTP and community campsites and game farms but these job opportunities were not only seasonal (during winter months when more tourists visit the Kalahari) but also few. Further, $32 \%$ of the respondents reported that their children had gained game guiding and tracking skills, thanks to community training programmes. 
Thus, in general, benefits from ecotourism initiatives at the KTP have been lower than expected as the money has so far been used for infrastructure development with no real tangible benefits cascading to household level. This has resulted in lack of interest in community activities, as evidenced by reported unwillingness to attend community meetings. Despite the absence of a functional CPA Management Committee, the respondents reported that CPA Annual General Meetings were being convened by the members of the Park Committee. Asked if they had attended the most recent community Annual General Meeting, about $76 \%$ of respondents (second survey) said they had not attended. They reported that they no longer participated in community activities, since such activities were not only timeconsuming but also did not directly contribute to their livelihoods.

Despite the fact that the rubric of benefit sharing is used to bring different actors into collaborative agreements (Borsch and Hirschfeld, 2002), evidence on the ground suggests that benefits promises are only partly fulfilled. Our results are generally comparable with findings by Moswete et al. (2012) on the Botswana side of the Kgalagadi Transfrontier Park where adjacent local communities perceive lack and inequality of benefits from the park. Findings by Tumusiime and Vedeld (2012) in Uganda also suggest that despite efforts for collaborative governance, collective action is undermined by limited levels of income derived from tourism enterprises. In a recent study in Namibian conservancies, Silva and Mosimane (2013) found that disillusionment with economic benefits was the major reason for nonparticipation of community members in community-based meetings and forums. The income generated from these enterprises is often insufficient to compensate landowners adequately for their sacrifice of other livelihood options such as agriculture and use of natural resources. 


\subsection{Information dissemination, accountability and transparency}

At household level, $92 \%$ of the respondents in the second survey mentioned a lack of information dissemination from the Financial Committee and the San Park committee (San representatives in the Joint Management Board) regarding community projects (e.g. community game farms and the lodge in the Contract Park) in terms of the annual budget, animal numbers, hunting quotas, selling price of animals, amount of cash income generated and community expenditure. These respondents reported that no financial report had been presented to them in previous years and as expected, perceived that the finances were badly accounted for and did not trust the appointed financial administrators to manage and account for finances - and they were no longer interested in collective action. Collomb et al. (2010) argue that local power dynamics could influence whether or not information is shared and the type and amount of information disclosed to hold on to power.

We generally found it difficult to get information on community income and expenditure. All the interviewed Financial Committee members were unwilling to disclose information on income generated from community game farms and bush camps. This could be attributed not only to poor book-keeping but also (as respondents highlighted) to the fact that the cash income did not fairly benefit all community members. It was reported that some of this income was spent to cover local household debts (for households who take food parcels on credit in local shops). However, the criteria in which households benefitted from this scheme were overwhelmingly reported to be unfair. When assessing the relationships between community members and local leaders, $74 \%$ of the respondents surveyed in the second phase said the relations were either 'unsatisfactory or highly unsatisfactory' due to mistrust. 
Thus, despite the fact that, in principle, land settlement agreements are based on principles of visibility and conveyance of information regarding performance of collaborative activities (Lockwood et al., 2010), our findings suggest that this was non-existent. This has subsequently fueled distrust between the local conservation authorities and some sections of the local communities - an expected outcome given that "distrust is one of the main barriers to collaboration" (Redpath et al., 2013: 102). Lack of transparency with respect to benefitssharing is also reported as one major factor behind local people's reluctance to participate in collaborative activities at the KTP in Botswana (Motswete et al., 2012).

\section{Conclusions and recommendations}

In examining the interplay between local institutions, actors and collective action for collaborative governance of natural resources at the Kgalagadi Transfrontier Park (KTP), key lessons with wider significance emerge. Generally our findings illustrate that the institutional landscape for collaborative governance is complex and characterised by unequal power relations, while the diversity of actors with diverse interests adds another layer of complexity. Though the complexity of decentraised or participatory arrangements is well documented, the continued pursuit of collaborative governance as an outcome of settled land claims on South African parks demands further scrutiny.

First, while settlement agreements are based on principles of inclusiveness, fairness and participation decision, local institutions are more often than not restrictive and do not promote participation of all actors. Further, despite that actors, especially local communities, are brought together by the promises of benefits, the benefits seldom materialise in any significant way which yields resistance to collaborative governance. This has subsequently led to conflicts over natural resource use in parks and is responsible for a high level of 
dissatisfaction, distrust and lack of interest in collaborative governance as demonstrated in this case study and elsewhere (e.g. Mwakaje et al., 2013; Silva and Mosimane, 2013). What this study shows is that communities are unlikely to invest in collaborative governance unless local institutions can ensure the benefits of this outweigh the costs. In the case of the KTP, lack of benefit accrual maybe attributed to unsuitability of the arid environment to make a modern living. The Kalahari region is a marginal environment, from an ecological and agricultural point of view, hence livelihood options are limited. Thus, there is a compelling need for a pragmatic approach to collaborative governance, in terms of what is practically possible for benefit accrual given population sizes and carrying capacities of ecosystems.

The second lesson is it appears that while collaborative arrangements are in principle underlain by undertones of equal power sharing, the state often wields more power than the local community actors (Adams and hutton, 2007; Davies and White, 2012). In most collaborative arrangements worldwide, the state initiates collaborative activities, though it has an interest to maintain or extend areas under protection in line with international biodiversity obligations (Brockington et al., 2006; Cundill et al., 2013). In such cases, protection of resources has won at the expense of local livelihoods. Thus, the role of the state as an interested actor and facilitator for collaborative governance needs to be questioned. We suggest as others have (e.g Davies and White, 2012; Cundill et al., 2013) that the state has vested interests in conservation, hence neutral actors should mediate and facilitate collobarative resource management if the decision-making landscape is to be levelled.

Thirdly, it seems that heterogeneity matters in collaborative governance intiatives even among indigenous communities assumed to be homogenous (Robins, 2001; Thondhlana and Shackleton, 2013) - as evidenced by the traditionalist-modernist dichotomy. This means that 
local institutions crafted on the assumption of homegeniety are unlikely to serve the diverse interests and priorities of local communities. Further, in the context of South Africa, community conflicts seem to be a product of the land restitution legal system that requires communities to form large groups for them to qualify to lodge a land claim (Ellis. 2010; Thondhlana et al., 2011, Cundill et al., 2013). This means that individuals coming from diverse historical and cultural backgrounds, and understandibly with different interests, come together for a land claim, lured by the prospects of, among other things, benefit-sharing. In reality though, community members have varying interests - which presents a complication for defining common visions and goals expected in collaborative governance arrangements. Inititives such as ecotourism partnerships, often pitched as vehicles for economic development and poverty alleviation, look positive, but we question whether or not the insitutions for benefit sharing can equitably provide opportunities to community members with diverse interests. It is our view that institutions developed within a rigid 'homogenous' traditionalist mould such as those at the KTP are unrealistic as they restrict resource access and involvement in decision-making by users with different livelihood interests (e.g. livestock grazing) perceived to be incompatible with conservation.

To sum up, there is little doubt that considerable progress has been made in understanding the efficacy of local institutions in fostering collaborative governance of natural resources in parks and their surrounds. Despite the promise of collaborative approaches, conservation policies should consider how local institutions can provide incentives for or pose constraints to participation by community members. A deeper understanding of institutions needs to zero down to examine as Shackleton et al. (2010) suggest, what and whose interests are protected, who gains, who loses and what institutional mechanisms can be developed to promote greater access and use rights, security of such rights, equity and justice between actors in 
collaborative governance arrangements in and beyond parks. We recommend that local institutions should be (re)configured to allow active participation by all actors in decisionmaking, information sharing and equitable access to natural resources (see Lockwood et al., 2010; Cundill et al., 2013; Moorman et al., 2013) if collaborative governance is to be achieved. With the likelihood of multiple actors in collaborative arrangements, there is need for a careful consideration of how the different roles and responsibilities of actors are defined, definition of common values and setting of realistic goals among actors, while ensuring a transparent decision-making process and building trust in all institutional networks to minimise tensions.

\section{Acknowledgements}

We thank the San people for their willingness to participate in the surveys. We are grateful to the International Foundation for Science - Sweden, Grant No. S/4873-1, for funding. We thank three anonymous referees for their insightful comments.

\section{References}

Adams, W.M. and Hutton, J., 2007. People, parks and poverty: political ecology and biodiversity conservation. Conservation and Society 5(2): 147-183.

Bosch, D., Hirschfeld, E., 2002. The Ae! Hei Kalahari Heritage Park Bundle. Pretoria, South Africa: Commission on Restitution of Land Rights.

Bradstock, A., 2006. Land reform and livelihoods in South Africa's Northern Cape Province. Land Use Policy 23(3): 247-259.

Brockington, D., Igoe, J., Schmidt-Soltau, K., 2006. Conservation, human rights and poverty reduction. Conservation Biology 20(1): 250-252.

Campbell, B., Mandondo, A., Nemarundwe, N., Sithole, B., De Jong, W., Luckert, M. Matose, F., 2001. Challenges to proponents of common property resource systems: despairing voices from the social forests of Zimbabwe. World Development 29(4): 589-600.

Campbell, B., Sayer, J., Frost, P., Vermeulen, S., Perez, M.R., Cunningham, A.B., Prabhu, R., 2001. Assessing the performance of natural resource systems. Ecology and Society 5, 22. 
Coe, C.A., 2013. Local power structures and their effect on forest land allocation in the Buffer Zone of Tam Dao National Park, Vietnam. Journal of Environment \& Development 22(1): 74-103.

Collomb, J.G.E., Mupeta, P., Barnes, G., Child, B., 2010. Integrating governance and socioeconomic indicators to assess the performance of community-based natural resources management in Caprivi (Namibia). Environmental Conservation 37(3): 303-309.

Cundill, G., Thondhlana, G., Sisitka, L., Shackleton, S., Blore, M., 2013. Land claims and the pursuit of comanagement on four protected areas in South Africa. Land Use Policy 35: 175-178.

Davies, A.L., White, R.M. 2012. Collaboration in natural resource governance: reconciling stakeholder expectations in deer management in Scotland. Journal of Environmental Management, 112: 160-169.

Ellis, W., 2010. The \#Khomani San land claim against the Kalahari Gemsbok National Park: Requiring and acquiring authenticity. In Land, memory, reconstruction and justice. eds, Walker, C., A. Bohlin, R. Hall and T. Kepe. pp. 181-197 Ohio, Ohio University Press.

Finer, M., Vijay, V., Ponce, F., Jenkins, C.N., Kahn, T.R., 2009. Ecuador's Yasuni Biosphere Reserve: a brief modern history and conservation challenges. Environmental Research Letters 2: 1-15.

Graham, J., Amos, B. and Plumptre T., 2003. Governance principles for protected areas in the 21st century. Ottawa: Institute on Governance, Parks Canada and the Canadian International Development Agency.

Hanks, J., 2003. Transfrontier Conservation Areas (TFCAs) in southern Africa: their role in conserving biodiversity, socioeconomic development and promoting a culture of peace. Journal of Sustainable Forestry, 17(1-2): 127- 48.

Holden, P., 2007. Conservation and human rights - the case of the $\neq$ Khomani San Bushmen and the Kgalagadi Transfrontier Park, South Africa. Policy Matters, 15: 57-68.

Holmes-Watts, T., Watts, S., 2008. Legal frameworks for and the practice of participatory natural resources management in South Africa. Forest Policy and Economics 10 (7-8): 435-443.

Jones, B.T., 2007. Synthesis of the CBNRM policy and legislation in Botswana, Malawi, Mozambique, Namibia, Zambia, and Zimbabwe. WWF-SARPO Occasional Paper, No. 16. Harare, Zimbabwe: WWF-SARPO.

Kepe, T.V., 2008a. Beyond the numbers: Understanding the value of vegetation to rural livelihoods in Africa. Geoforum 39(2): 958-968.

Kepe, T. 2008b. Land claims and co-management of protected areas in South Africa: Exploring the challenges. Environmental Management 41: 311-321.

Kepe, T., Wynberg, R., Ellis, W., 2005. Land reform and biodiversity conservation in South Africa: complementary or in conflict? International Journal of Biodiversity Science and Management 1(1): 3-16.

Lockwood, M., Davidson, J., Curtis, A., Stratford, E. and Griffith, R., 2010. Governance principles for natural resource management. Society and Natural Resources 23(10): 986-1001.

Moorman, M.C., Peterson, N., Moore, S.E., Donoso, P.J., 2013. Stakeholder perspectives on prospects for comanagement of an old-growth forest watershed near Valdivia, Chile. Society \& Natural Resources 26(9): 1022-1036. 
Moswete, N.N., Thapa, B. and Child, B., 2012. Attitudes and opinions of local and national public sector stakeholders towards Kgalagadi Transfrontier Park, Botswana. International Journal of Sustainable Development \& World Ecology 19(1): 67-80.

Mucina, L., Rutherford, M.C., (Eds), 2006. The vegetation of South Africa, Lesotho and Swaziland. Pretoria (South Africa): South Africa National Biodiversity Institute.

Mwakaje, A.G., Manyasa, M., Wawire, N., Muchai, M., Ongare, D., Mugoya, C., Masiga, C.W., Nikundiwe, A., 2013. Community-Based Conservation, Income Governance, and Poverty Alleviation in Tanzania: The Case of Serengeti Ecosystem. Journal of Environment \& Development 22(1): 51-73.

Ostrom, E., 1990. Governing the commons: The evolution of institutions for collective action. Cambridge: Cambridge University Press.

Petursson, J.G., Vedeld, P., Kabogoza, J., 2011. Transboundary biodiversity management: Institutions, local stakeholders and protected Areas: A case study from Mt. Elgon, Uganda and Kenya. Society and Natural Resources 24: 1304-1321.

Petursson, J.G., Vedeld, P., Sassen, M., 2013. An institutional analysis of deforestation processes in protected areas: The case of the transboundary Mt. Elgon, Uganda and Kenya. Forest Policy and Economics, 23: $22-33$

Ramutsindela, M., 2007. Transfrontier conservation in Africa: At the confluence of capital, politics and nature. Wallingford and Boston MA: CABI

Redpath, S.M., Younh, J., Evely, A., Adams, W.M., Sutherland, W.J., Whitehouse, A., Amar, A., Lambert, R.A., Linnel, J.D.C., Watt, A., Gutierrez, R.J., 2013. Understanding and managing conservation conflicts. Trends in Ecology \& Evolution 28(2): 100-108.

Robins, G., 2001. NGO's 'Bushmen' and double vision. The Khomani San land claim and the cultural politics of 'Community' and 'Development' in the Kalahari. Journal of Southern African Studies 27(4): 833-853.

SAHRC (South African Human Rights Commission), 2004. Report on the inquiry of human rights violations in the Khomani San community. Andriesvale-Askham Area, Kalahari.

SANParks. 2006. Kgalagadi Transfrontier Park, Park Management Plan. Ref No. 16/1/5/1/5/11/1. http://www.sanparks.org/parks/kgalagadi/. [Accessed 29 May 2013].

Shackleton, C.M., Willis, T.J., Brown, K., Polunin, N.V.C., 2010. Reflecting on the next generation of models for community-based natural resources management. Environmental Conservation 31(1): 1-4.

Silva, J.A., Mosimane, A.W., 2013. Conservation-based rural development in Namibia: a mixed method assessment of economic benefits. Journal of Environment \& Development 22(1): 25-50.

Springer, J., 2009. Addressing the social impact of conservation: lessons from experience and future directions. Conservation and Society 1(1): 26-29.

Thondhlana, G., Vedeld, P., Shackleton, S., 2012. Natural resource use, incomes and dependence amongst the San and Mier communities bordering Kgalagadi Transfrontier Park in the southern Kalahari, South Africa. International Journal of Sustainable Development \& World Ecology 19(5): 460-470.

Thondhlana, G., Shackleton, S., 2015. Cultural values of natural resources among the San people neighbouring Kgalagadi Transfrontier Park, South Africa. Local Environment: The International Journal of Justice and Sustainability 20(1): 18-33 
Thondhlana, G., Shackleton, S., Muchapondwa, E., 2011. Kgalagadi Transfrontier Park and its land claimants: A pre- and post-land claim conservation and development history. Environmental Research Letters 6(2): 1-12.

Tumusiime, D., Vedeld, P., 2012. False promise or false premise. Using tourism revenue sharing to promote conservation and poverty reduction in Uganda. Conservation \& Society 10(1): 15-28.

United Nations. 1994. Draft United Nations Declaration on the Rights of Indigenous Peoples. Office of the United Nations High Commissioner for Human Rights Geneva, Switzerland.

van Rooyen, A. F., 1998. Combating desertification in the southern Kalahari: connecting science with community action in South Africa. Journal of Arid Environments 39: 285-98.

Vedeld, P. Jumane, A., Wapalila, G. and Songorwa, A., 2012. Protected areas, poverty and conflicts: A livelihood case study of Mikumi National Park, Tanzania. Forest Policy and Economics 21: 20-31.

Young, O.R., 2002. The institutional dimension of environmental change. Fit, interplay and scale. London: Cambridge MA: The MIT press. 